\title{
The Association Between the Knowledge of Oral Hygiene of Mothers Who Chewing Betel Leaves and Their Oral Condition in Lingkungan II Lau Cih, Medan Tuntungan
}

\author{
Nelly Katharina Manurung ${ }^{1}$, Ngena Ria ${ }^{1} \&$ Susy Adrianelly Simaremare ${ }^{1}$ \\ ${ }^{1}$ Poltekkes Kemenkes Medan, Indonesia \\ Correspondence: Ngena Ria, Poltekkes Kemenkes Medan, Jl. Jamin Ginting Km 13.5 Kel Lau Cih, Kec. Medan \\ Tuntungan, Medan, Indonesia. Tel: 62-061-836-8633.E-mail: ngena_ria@yahoo.com
}

Received: June 1, 2020 Accepted: July 10, 2020 Online Published: July 20, 2020

doi:10.5539/gjhs.v12n9p145 URL: https://doi.org/10.5539/gjhs.v12n9p145

\begin{abstract}
The habit of chewing betel leaves are the habit of chewing betel leaves with other additives ingredients for adding the pleasure of taste. Chewing betel leaves becomes daily habit for people, especially mothers who believe it can strengthen their teeth. This research employed an analytical survey with cross sectional design, aiming to find out the relationship between the knowledge of oral hygiene of mothers who chewing betel leaves and their oral condition. This research found that there is no relationship between the knowledge of mothers who chewing betel leaves on oral hygiene and their oral condition. However, there is association between the duration of chewing betel leaves and oral hygiene $(\mathrm{p}=0.002)$ as well as caries experience $(\mathrm{p}=0,011)$. Mothers who chewing betel leaves have poor oral hygiene and high caries experience.
\end{abstract}

Keywords: knowledge, oral hygiene, chewing betel leaves

\section{Introduction}

Health in general is a situation where body, soul and social well-being make someone's life productive in terms of social and economy. Health, therefore, is essential for human life. Healthcare aims to increase people awareness, willingness and ability on healthy life in order to achieve a healthy society. Oral hygiene is essential for human health and well-being in general. It significantly affects the quality of life, including the function of talking, chewing and self-confidence (Baiju et al., 2017; Ria \& Putri, 2018). Teeth are integrated with other parts of the body. If there is a problem on teeth, it could affect the health of other parts of the body and therefore disturbing our daily activities (Broder \& Sischo, 2011). The effort for dental health should be seen from several aspects: environment, knowledge, education, public awareness and management of dental health including preventing action and treatment. However, many people ignore the overall dental health condition. Dental care is seen as unimportant concern, although it is worth very vital in supporting health and appearance. A common oral disease which is found in society is dental caries and periodontal disease (Agrawal et al., 2015).

Knowledge results from an understanding after people observing a particular object. Sensing or observing is conducted through five human senses, namely seeing, hearing, smelling, tasting and touching. Most human knowledge is obtained through their eyes and ears. Thus, knowledge is powerful to change a habit and to form a particular behavior, especially maintaining oral hygiene. Habit is defined as a regular activity of people.

Betel is a plant originally grown in Indonesia growing through vine or resting on trunks of a tree. Betel leaf belongs to the family Piperaceae. The betel plant is a slender, aromatic creeper, rooting at the node. It has an alternate, heart shaped, smooth and long stalked leaves with pointed apex. Betel is originated from central and eastern part of Malaysia. It is widely cultivated in many parts of India. Basically, a mixture of betel leaves is chewed with areca nut, gambier (Uncaria Gambir Roxb) and lime, the composition of which varies in different populations and countries. Then tobacco is used for cleaning teeth (Gupta \& Warnakulasuriya, 2002; Parmar et al., 2008; Garg, Chaturvedi, \& Gupta, 2014)

Gupta and Warnakulasuriya (2002), reported that a substantial proportion of the world's population is engaged in chewing areca nut, and that the habit is endemic throughout the Indian subcontinent, large parts of south Asia and Melanesia. The tradition of chewing betel leaves is a habit of people and the practice influences oral hygiene. However, chewing betel leaves has been linked to the mouth cancer and also can form squamous cell carcinoma 
which is malignant to the mouth (Oaklay et al., 2005). Chatrchaiwiwatana (2006), stated that reduce the habit of chewing betel quid so that healthy periodontal tissue can be maintained. Culturally, the tradition of chewing betel leaves plays an important role in society. Such as social acceptability, religious beliefs, perceived health benefits, and addiction (Anand et al., 2014). Chewing betel leaves is commonly practiced in local ceremonies as a way to respect or reverguests. It is a daily habit which is believed to have a positive impact to strengthen teeth.

\section{Methods}

\subsection{Research Design}

This study was an observational analytical research with crosssectional design, aiming to find out the association between the knowledge of oral hygiene of mothers who chewing betel leaves and their oral condition.

\subsection{Population and Sample}

Total population of mothers who have the habit of chewing betel leaves in Lingkungan II Lau Cih, Medan Tuntungan is 57 people. This research used a purposive sampling method. From 57 mothers who chewing betel leaves, only 30 mothers fill the criteria as sample. Inclusion criteria: Mothers who still have a habit of chewing betel leaves when this research was conducted, mothers who have a habit of chewing betel leaves more than three years.

Materials: The materials for conducting this research were questionnaire, examination form, cotton, alcohol, dental sonde, dental mirror, tweezers, excavator, and nierbekken.

\subsection{Data Collection Method}

Ethical clearance for the study was obtained from the Ethics Committee Politeknik Kesehatan Kemenkes Medan.

The research was performed by the following steps: filling informed consent by subjects that were guided by researcher, recording subject complete identity in the status form and filling questionnaire by subjects individually. Data of the knowledge of mothers was gathered from questionnaire are: 1. Brushing habits (when, frequency, duration/ length of time and method), 2. Selection of good toothbrush, 3. Types of food that makes teeth healthy,

4. Betel habits (how long does it take to betel, how many times a day, and how to clean the teeth after chewing).

Data of oral hygiene was obtained from direct observation of oral cavity to all respondents followed by examination format performing examination for subject oral hygiene condition (OHI-S). Oral Hygiene IndexSimplified (OHI-S) is influenced by the behavior of maintaining dental and oral health.

OHI-S is composed of the Debris Index (DI) and Calculus Index (CI). Each of these indices is based on 12 numerical determinations representing the amount of debris or calculus found on the buccal and lingual surfaces of each of six segments of each dental arch. Each segment is examined for debris or calculus. From each segment, one representative tooth is used for calculating the individual index. The representative tooth used for the calculation must have the greatest area covered by either debris or calculus. The average debris and calculus scores are combined to obtain the OHI, which ranges from 0 to 6 (Greene, Vermilion, 1964).

Debris Index (DI)

Scoring System Score 0: Absence of debris 1: Soft debris covering less than the cervical one-third of the tooth surface. 2: Soft debris covering more than the cervical one-third of the exposed tooth surface but less than the cervical two-thirds. 3: Soft debris covering more than the cervical twothirds of the exposed tooth surface.

\section{Calculus Index (CI)}

Scoring System: Score 0: Absence of calculus 1: Calculus covering less than the cervical one-third of the exposed tooth surface. 2: Supragingival calculus covering more than the cervical one-third, but not more than the cervical two-thirds of the exposed tooth surface, or presence of individual flecks of subgingival calculus around the cervical portion of the tooth. 3: Supragingival calculus covering more than the cervical two-thirds of the exposed tooth surface, or a continuous heavy band of subgingival calculus around the cervical portion of the tooth. OHI-S score for each individual was obtained by combining the Debris Index and the Calculus Index. OHI-S = DI + CI. OHI- $\mathrm{S}$ values range from 0 to 6 . The clinical levels of oral hygiene that can be associated with group OHI-S scores are as follows; Good: 0.0 to 1.2; Fair: 1.3 to 3.0; Poor: 3.1 to 6.0.

\section{Dental Caries}

Dental caries can be measured by DMF-T index. The prevalence of caries is a value that reflects the number of caries sufferers in a given period and time. The DMF-T index is a measurement index that shows the number of teeth with caries in a person or group of people. Decay (D) is a tooth with a cavity due to dental caries, Missing(M) 
is indicated for extraction because caries, Filling $(\mathrm{F})$ is filled or restored due to caries, and $\mathrm{T}$ is teeth. DMF-T is the sum of $\mathrm{D}+\mathrm{M}+\mathrm{F}$.

Univariant analysis was used to see the distribution of frequency of the retrospective variables. Data from questionnaires were manually entered in the Microsoft excel spreadsheet. Bivariant analysis is to analyse the association of the independent variable and dependent variable as well as taking the Chi Square test.

\section{Results}

Description on the level of mothers' knowledge on oral hygiene in Lingkungan II Lau Cih, Medan Tuntungan using univariate analysis is depicted as follows:

Table 1. Level of knowledge on oral hygiene of mothers

\begin{tabular}{lll}
\hline Level of knowledge & $\mathrm{n}$ & $\%$ \\
\hline Good & 18 & 60 \\
Average & 12 & 40 \\
Poor & 0 & 0 \\
\hline Total & 30 & 100 \\
\hline
\end{tabular}

Table 2. Oral Condition of Mothers

\begin{tabular}{ll}
\hline Oral condition & Average \\
\hline Oral hygiene Debris Index (DI) Calculus Index (CI) & 1,3 \\
Oral Hygiene Index-Simplified (OHI-S) & 1,9 \\
& 3,2 \\
\hline Caries experience Decay (D) Missing(M) Filling (F) & 2,8 \\
DMF-T & 6,0 \\
& 0,1 \\
& 8,9 \\
\hline
\end{tabular}

Table 3. Percentage of Status of Oral Hygiene Index Simplified and Caries Experience (Decay Missing Filled-Teeth)

\begin{tabular}{lll}
\hline Oral Condition & $\mathrm{n}$ & $\%$ \\
\hline Level of oral hygiene (OHI-S) Good & 0 & 0 \\
Average Poor & 14 & 46,7 \\
& 16 & 53,3 \\
\hline Caries experience (DMF-T) & 3 & \\
$\leq 2$ & 30,0 \\
$>2$ & 27 & 90,0 \\
\hline
\end{tabular}


Table 4. Habit of Chewing betel leaves of Mothers

\begin{tabular}{lll}
\hline Chewing betel leave habit & $\mathrm{n}$ & $\%$ \\
\hline Duration of chewing & 2 & \\
$\leq 10$ minutes & 28 & 6,7 \\
$>10$ minutes & & 93,3 \\
\hline Frequency of chewing & 8 & 26,7 \\
$\leq$ twice a day & 22 & 73,3 \\
$>$ twice a day & & \\
\hline How to clean the teeth / mouth after chewing Brushing teeth & 8 & 26,7 \\
Gurgling & 5 & 16,7 \\
Consume nut and limestone & 17 & 56,6 \\
\end{tabular}

Using bivariate analysis, the relationship between mothers' knowledge on oral hygiene and the oral condition can be drawn from the analysis of Chi Square Test. The analysis stated that the duration of chewing betel leaves has an impact to OHI-S with value $\mathrm{p}=0,002(\mathrm{p}<\alpha)$ and DMF-T with value $\mathrm{p}=0,011(\mathrm{p}<\alpha)$.

\section{Discussion}

The research found that $60 \%$ respondents have good knowledge on oral hygiene, $40 \%$ have average knowledge, and none with poor knowledge. Knowledge is a person ability to reveal what she found on oral or written answers, which considered as reaction from stimulation of the question. Thus, knowledge or cognitive is very important domain to form an action.

Most respondents (56.7\%) know the right time to brush their teeth. According to American Dental Association (ADA) the ideal time of regular brushing teeth is at least twice a day i.e. in the morning after breakfast and evening before sleeping. Most respondents (66.7\%) know how to choose the right type of teeth brush to be used. According to the ADA, the soft brush is the proper one (Baruah et al., 2017). Many people do not know how to remove plaque. They think that hard brush is the better one because it functions to remove plaque better. However, the hard brush is actually less flexible and cannot be bent properly; therefore it cannot reach the area under the gums and the teeth which are the most important part to be cleaned.

The results of the examination of oral hygiene on 30 respondents achieved OHI-S average at 3.2. Debris is the remnants of food that was left in the mouth, on the surface of the teeth, in between teeth and below the gingiva after eating. Generally debris is easily cleaned by moving the lips, cheeks, tongue and also gargles. Although the debris contains bacteria, it is different from the plaque and materia alba. It is also easier to be removed. The speed of cleaning debris from the oral cavity varies according to the type of food and individual person.

Calculus or tartar is hard sediment that lies on the surface of the tooth and colored ranging from yellow to blackish with rough surface. Tartar can occur due to the activity of the phosphate enzymes derived from mucosal surfaces cells that generate. Usually the phosphate enzyme is formed when there is an inflammation (Ingham et al., 2002). The results of direct examination to 30 respondents showed that $46.7 \%$ have average oral hygiene while $53.3 \%$ respondents have good oral hygiene. Respondents who chew betel for more than 10 minutes are $93.3 \%$ respondents, while $73.3 \%$ respondents have frequency of chewing betel more than twice a day. Oral hygiene of mothers who have chewing betel leaves could be influenced by many factors such as duration of chewing betel mixed, frequency of chewing in a day and it could also affected by the presence of limestone elements in the betel mixed that causes an atmosphere of bases in the mouth (Aziz, 2010).

The result of direct examination to 30 respondents showed that the attainment of Decay (D) in average was 2.8; the average of Missing (M) was 6.0; the average of Filling (F) 0.1; and the attainment of the DMF-T average was 8.9. Dental caries are still experienced by many adults around the world and precaution are needed (Simone et al., 2013). Dental caries process is chronic regressive process, started with the soluble of enamel mineral, which cause the disruption of the balance between enamel and its surroundings. This unbalance is caused by the formation of microbial acid of the substrate (medium food for bacteria) followed by the destruction of organic components which make cavitation. The process of caries starts from the presence of plaque on tooth surfaces, sucrose from the left overs and bacterial processes attached to a specific time which turns into lactic acid which lowers the $\mathrm{pH}$ of the 
mouth becoming critical (5.5) that will cause demineralizes of enamel continued to be dental caries.

Based on the results of the study note that half of respondents have good knowledge and the average OHI-S was poor. DMF-T index of all mothers was 8.9, which mean that an individual had an average of 8 to 9 teeth infected by caries. Based on WHO, the value of DMF-T index above 6.6 was the very high concerning the severity of caries. From the existing conditions it is known that good knowledge is not always followed by attitudes and practice in maintaining dental hygiene.

\subsection{Limitation of the Study}

1) The minimum sample size has not been able to review the same conditions in large number of respondents.

2) Using s questionnare where as sometimes the answers given by respondents do not show reality.

\section{Conclusion}

This research on the relationship between the knowledge of oral hygiene of mothers who chewing betel leaves and their oral condition in Lingkungan II Lau Cih, Medan Tuntungan can be concluded as follows:

1) OHI-S of respondents in Lingkungan II Lau Cih, Medan Tuntungan is in poor level (53.3\% respondents) and $90 \%$ respondents have high caries experience, with Decay Missing Filled Teeth (DMF-T) $>2$.

2) There are $93.3 \%$ of respondents who spend chewing betel leaves within 10 minutes and $73 \%$ of respondents chew betel leaves two times a day, while $56.6 \%$ respondents consumenut and limestone to clean their teeth and mouth after chewing betel leaves.

3) From this study, it can be concluded that there is no significant association between the knowledge of oral hygiene of mothers who chewing betel leaves and their oral condition in Lingkungan II Lau Cih Medan Tuntungan. Nevertheless. There is a strong association between the duration of chewing betel leaves and oral hygiene $(\mathrm{p}=0.002)$, as well as with caries experience $(\mathrm{p}=0.011)$.

\section{Competing Interests Statement}

The authors declare that there are no competing or potential conflicts of interest.

\section{References}

Agrawal, R., Gautam, N. R., Kumar, P. M., Kadhiresan, R., Saxena, V., \& Jain, S. (2015). Assessment of dental caries and periodontal disease status among elderly residing in old age homes of Madhya Pradesh. Journal of international oral health: $\mathrm{JIOH}, 7(8), 57$.

Anand, R., Dhingra, C., Prasad, S., \& Menon, I. (2014). Betel nut chewing and its deleterious effects on oral cavity. Journal of cancer research and therapeutics, 10(3), 499.

Aziz, S. R. (2010). Coming to America: betel nut and oral submucous fibrosis. The Journal of the American Dental Association, 141(4), 423-428.

Baiju, R. M., Peter, E. L. B. E., Varghese, N. O., \& Sivaram, R. (2017). Oral health and quality of life: current concepts. Journal of clinical and diagnostic research: JCDR, 11(6), ZE21.

Baruah, K., Thumpala, V. K., Khetani, P., Baruah, Q., Tiwari, R. V., \& Dixit, H. (2017). A review on toothbrushes and tooth brushing methods. International Journal of Pharmaceutical Science Invention, 6(5), 29-38.

Supaporn Chatrchaiwiwatana, D. D. S. (2006). Dental caries and periodontitis associated with betel quid chewing: analysis of two data sets. J Med Assoc Thai, 89(7), 1004-11.

Garg, A., Chaturvedi, P., \& Gupta, P. C. (2014). A review of the systemic adverse effects of areca nut or betel nut. Indian journal of medical and paediatric oncology: official journal of Indian Society of Medical \& Paediatric Oncology, 35(1), 3. https://doi.org/10.4103/0971-5851.133702

Sischo, L., \& Broder, H. (2011). Oral health-related quality of life: what, why, how, and future implications. Journal of dental research, 90(11), 1264-1270. https://doi.org/10.1177/0022034511399918

Greene, J. G., \& Vermillion, J. R. (1964). The simplified oral hygiene index. The Journal of the American Dental Association, 68(1), 7-13. https://doi.org/10.1080/13556210020091437

Ingham, K. E., Gorrel, C., Blackburn, J. M., \& Farnsworth, W. (2002). The effect of toothbrushing on periodontal disease in cats. The Journal of nutrition, 132(6), 1740S-1741S. https://doi.org/10.1093/jn/132.6.1740S

Oakley, E., Demaine, L., \& Warnakulasuriya, S. (2005). Areca (betel) nut chewing habit among high-school children in the Commonwealth of the Northern Mariana Islands (Micronesia). Bulletin of the World Health 
Organization, 83, 656-660.

Moynihan, P., \& Petersen, P. E. (2004). Diet, nutrition and the prevention of dental diseases. Public health nutrition, 7(1a), 201-226.

Parmar, G., Sangwan, P., Vashi, P., Kulkarni, P., \& Kumar, S. (2008). Effect of chewing a mixture of areca nut and tobacco on periodontal tissues and oral hygiene status. Journal of oral science, 50(1), 57-62. https://doi.org/10.2334/josnusd.50.57

Ria, N., \& Eyanoer, P. (2018). Association of Tooth Brushing Behavior with Oral Hygiene Index among Students Using Fixed Appliance. IOP Conf. Series: Earth and Environmental Science, 125(2018), 012200. https://doi.org/10.1088/1755-1315/125/1/012200

Sandeep, K. E. (2012). A Novel Neural Network Based Approach for The Classification of Betel Leaves. Inter $J$ Emerg Trends Tech in Comp Scie, 1, 10.

Simone, M. C., Mara, V., \& Mauro, H. N. G. A. (2013). High Dental Caries among Adults Aged 35 to 44 Years: Case- Control Study of Distal and Proximal Factors. Int J Environ Res Public Health, 10, $2401-2411$. https://doi.org/10.3390/ijerph10062401

\section{Copyrights}

Copyright for this article is retained by the author(s), with first publication rights granted to the journal.

This is an open-access article distributed under the terms and conditions of the Creative Commons Attribution license (http://creativecommons.org/licenses/by/4.0/). 